Western University Scholarship@Western

Law Publications

Law School

2005

\title{
The Sutherland Report and the Theory of WTO Law
}

Chios Carmody

The University of Western Ontario

Follow this and additional works at: https://ir.lib.uwo.ca/lawpub

Part of the International Trade Law Commons

Citation of this paper:

Chi Carmody, "The Sutherland Report and the Theory of WTO Law" (2005) 2:1 Intl Organizations L Rev 219. 


\title{
The Sutherland Report and the Theory of WTO Law
}

\author{
By Chi Carmody ${ }^{1}$
}

The recent report of the Consultative Board to the WTO Director-General, referred to as the Sutherland Report, deals with a number of key issues in the present and future of WTO. Among them are globalization, non-discrimination, sovereignty, coherence, and dispute settlement. We can legitimately wonder what motivated this selection. After all, the WTO Agreement involves many issues. A casual review of the Sutherland Report might suggest that the Consultative Board simply chose those issues that have been the most politically sensitive for the organization and focused upon them.

Looked at more closely, however, something else becomes apparent. This is that there is a common thread to most of the issues dealt with in the Sutherland Report and that they can be understood in an integrated manner according to a theory of WTO law. The Consultative Board may not have expressed its findings and recommendations in such terms, but there should be little doubt that its work was motivated by a belief in legal principle.

This is an important insight, chiefly because most theories of the WTO as a treaty and an international institution come to us from either economics or politics. We are apt to regard the WTO Agreement's shape and operation as attributable to comparative advantage or power relations, or perhaps some combination of the two. The idea that there exists a coherent theory of WTO law seems somewhat suspect.

A number of factors reinforce such an attitude. One is the complexity of the WTO Agreement, a document which in its official version runs more than 26,000 pages and which contains a large number of obligations, not all of which fit together neatly. Simply put, the treaty is so big and unkempt that it often defies the legal imagination.

Another factor is WTO dispute settlement. Because the WTO Agreement is so complex, countries have been forced to litigate their disputes over interpretation of the treaty in dispute settlement. The process works reasonably well, but litigation does not always raise underlying principles of WTO law in the most comprehensive or consistent manner.

Still another factor is public perception. As the Consultative Board pointed out, the WTO is often seen through the prism of national concerns. "Members understandably portray the WTO in terms of domestic political preoccupations" it noted, "seldom on the basis of the principles that underlie the system." ${ }^{\prime 2}$ Such a partisan perspective tends to neglect the treaty's core values.

\footnotetext{
${ }^{1}$ Associate Professor and Canadian Director, Canada-U.S. Law Institute, Faculty of Law, University of Western Ontario, London, Ontario, Canada. N6A 3K7, email: ccarmody@uwo.ca.

${ }^{2}$ The Consultative Board to the Director-General, The Future of the WTO: Addressing Institutional Challenges in the New Millenium (2004) [hereinafter The Future], para. 361.
} 
That core begins with the realization the WTO is not concerned with trade per se, but rather with the protection of expectations about the trade-related behaviour of governments. This principle has been recognized in WTO dispute settlement on many occasions and was acknowledged by the Consultative Board in the Sutherland Report as follows:

The WTO is about providing opportunities - it does not provide guarantees nor does it provide all the conditions for participation in the global economy. In essence it says to governments: here are a set of market opportunities for your local firms or individuals, if they are competitive, could benefit from; here also are the rules under which they will operate in foreign markets and under which others must be allowed to operate in your market. ${ }^{3}$

The emphasis on expectations goes on to explain the Consultative Board's preoccupation with the erosion of the Most Favoured Nation (MFN) principle. MFN requires that all WTO members extend their most favourable trading concessions and commitments to all other WTO members "immediately and unconditionally". In essence, it assures that all WTO members have the same expectation of access to the domestic market of a member country. The Consultative Board rightly described it as being "at the heart of GATT" and as its "central organizing rule". 4

At the same time, the Consultative Board admitted that "nearly five decades after the founding of the GATT, MFN is no longer the rule; it is almost the exception." ${ }^{\text {In its }}$ place "a 'spaghetti bowl' of customs unions, common market, regional and bilateral free trade areas, preferences and an endless assortment of miscellaneous trade deals" has arisen. The trend is of concern because it detracts from the uniformity of MFN and therefore from the uniformity of expectations. Some recommitment to this principle is required, the Consultative Board implied, and that it should do so is hardly surprising. MFN is the lynchpin of the system.

However, recommitment to MFN is challenging for a number of reasons. One is the impact that a recommitment might have on the practice of WTO decision-making by consensus, the procedural equivalent of MFN. ${ }^{6}$ The Consultative Board appeared to appreciate the difficulty of calling for the reinforcement of MFN without a parallel reinforcement of consensus decision-making, currently the source of much paralysis in the WTO's operation. Probably as a consequence, the Sutherland Report's recommendation was relatively tempered on this vital point. ${ }^{7}$

\footnotetext{
${ }^{3}$ The Future, para. 45.

${ }^{4}$ The Future, para. 58.

${ }^{5}$ The Future, para. 60.

${ }^{6}$ The Future, para. 281.

${ }^{7}$ With respect to consensus decision-making the Consultative Board recommended only that the WTO General Council adopt a Declaration that a WTO member considering blocking a measure which otherwise enjoys broad support should only be allowed to block the consensus if it declares in writing that the matter is one of vital national interest and supply reasons for its decision. See The Future, Recommendation 25.
} 
A similar explanation could be given for the Consultative Board's cool attitude towards "variable geometry", or the idea that WTO obligations should differ for different members of the organization. Variable geometry is to countenance a WTO à plusieurs vitesses, something antithetic to the uniformity of MFN and yet, given the 'spaghetti bowl' mentioned above, arguably only a recognition of the prevailing state of affairs. Again, the Sutherland Report was cautious on this point.

A further difficulty with recommitment to MFN is the oft-expressed concern that the uniformity of "pure" MFN does not take adequate account of real world conditions in many developing countries. On this subject the Consultative Board took something of a mixed view. It referred to special and differential treatment for developing countries under the treaty as a potential trap, quoting from a 1990 study that "in the more rapidly growing [developing] economies, such as Korea; Chinese, Taipei; Turkey and others, there is little evidence that special and differential treatment has played much of a role in their strong performance." 8 Nevertheless, the Consultative Board was prepared to concede that "there is a strong case to be made that least-developed countries should have a contractual entitlement to capacity building support to implement new commitments in the WTO."

Each of the foregoing points illustrates the fact that, to some degree, the WTO Agreement involves more than more than simply the protection of ex ante expectations. Such protection can be seen as a base or "first position", but here and there under the treaty are rules that exist to allow governments to respond to ex post realities. While aware of the fundamental need to protect expectations about conditions as they might be, the treaty thus also takes into account certain conditions as they actually are. WTO disciplines on safeguards, certain types of subsidies and anti-dumping action can be said to fall in this second category. Such obligations are based on actual conditions and are more likely to involve real trade flows.

The distinction reveals a subtle tension in the treaty, something alluded to by the Consultative Board when it observes that "[n]either the WTO nor the GATT was ever an unrestricted free trade charter." In the Consultative Board's view:

... both were and are intended to provide a structural and functionally effective way to harness the value of open trade to principle and fairness. In doing so they offer security and predictability of market access advantages that are sought by traders and investors. But the rules provide checks and balances, including mechanisms that reflect political realism as well as free trade doctrine. It is not that the WTO disallows market protection, only that it sets some strict disciplines under which governments may choose to respond to special interests. ${ }^{10}$

\footnotetext{
${ }^{8}$ The Future, para. 99.

${ }^{9}$ The Future, para. 306.

${ }^{10}$ The Future, para. 39.
} 
Again, the Consultative Board's observations must be examined with care, but they appear to acknowledge that the treaty is something of a hybrid. The content of its legal rules is dictated by the need to accommodate both aspiration and reality.

The treaty's double aspect reveals something else too. This is about the nature of justice under the WTO Agreement. Classically there are two forms of justice: corrective and distributive. ${ }^{11}$ Corrective justice applies to private property and plays a rectificatory role in transactions. Thus, when a person is wrongfully deprived of their property they are entitled to have it returned or to be compensated. The implicit metric is equality: you get what you've lost. Distributive justice, by comparison, applies to the distribution of public goods such as "honour or money or other things that have to be shared among members of the political community." 12 It presupposes some socially agreed means of allotment. Consequently, the implicit metric is proportionate: you get what you're entitled to.

As matters now stand, justice under the WTO Agreement involves member countries taking each other before three-person panels where there is an alleged violation of the treaty. When the complaint is made out, the panel normally recommends that the offender bring its law "into conformity" with the WTO Agreement. Thereafter, if the parties cannot settle the matter, they may negotiate compensation among themselves as a temporary measure pending compliance or, as a "last resort", the plaintiff may seek authorization to retaliate by suspending concessions, again pending compliance. What kind of justice does this represent?

WTO rules concerning dispute settlement suggest that the nature of justice under the WTO Agreement is primarily distributive. Distributive justice explains why it is that the principal remedy under the WTO Agreement is a mere recommendation of conformity: in classic distributive fashion the recommendation insists on a return to conformity, thereby re-establishing the distribution of expectations. Distributive justice also explains why WTO remedies focus on prospective as opposed to retrospective relief: their aim is not so much to repair prior or existing damage as it is to re-establish expectations in future. Finally, distributive justice explains why the ultimate sanction in the system is the suspension of concessions: suspension effectively denies the wrongdoer their proportionate share of the system's benefit.

Nevertheless, distributive justice is not the whole story of justice under the WTO Agreement. Our observation that the treaty has an expectation-based and reality-based aspect to it is paralleled by a similar tension between distributive and corrective justice. Distributive justice is the dominant form of justice under the treaty, but an impulse towards corrective justice subsists, both because several WTO obligations give the appearance of corrective justice and because corrective justice appeals to our innate sense of what justice should be. For instance, a wrongfully levied anti-dumping duty raises calls for its return, even though the amount of the duty will have little to do with the breached expectations and is not commonly considered refundable under WTO law.

\footnotetext{
${ }^{11}$ ARISTOtLe, Nichomachean Ethics (R. Crisp ed.) 85 (2000).

${ }^{12}$ Ibid.
} 
Such a situation might well explain why the Consultative Board expressed concern with ongoing retaliation. Retaliation is a deviation from a theory of WTO law that plainly emphasizes conformity as a means of protecting expectations. Indeed, at some point it can begin to look a lot like corrective justice. The Consultative Board noted its concern in this regard, observing that the persistence of retaliation in a few high-profile cases has tended to confer an aura of legitimacy upon it:

The somewhat relaxed, even complacent, resort to such damaging trade action is becoming serious. Also, there are worries, in particular, that some countries, including some of the major trading partners, such as the U.S. and the EU, are acting in a recalcitrant manner, and not taking measures that would effectively, and in a timely manner, fulfill their obligations. ${ }^{13}$

The Consultative Board was similarly critical of suggestions to make compensation more automatic or to permit the recoupment of legal fees in WTO dispute settlement, observing that:

To allow governments to "buy out" of their obligations by providing "compensation" or enduring "suspension of obligation" also creates major asymmetries of treatment in the system. It favors the rich and powerful countries which can afford such "buy outs" while retaining measures that harm or distort trade in a manner inconsistent with the rules of the system. $^{14}$

The Consultative Board concluded that:

[s]ome experimentation in this regard could be useful, but great care must be exercised to be sure that monetary compensation is only a temporary fallback approach pending full compliance, otherwise the "buy out" problems will occur. ${ }^{15}$

One could, of course, ascribe significance to the Consultative Board's conclusions here since any acknowledgment of the option to "contract out" of WTO obligations might be construed as an endorsement of a fundamentally different view of the treaty. There may be some truth to that view. Again, however, we have to remember how limited and cautious the Consultative Board's pronouncement was on this point. Elsewhere the Board repeatedly reminded its audience that "it is extremely important that the major players follow a policy of conforming to the obligations outlined in WTO panel and Appellate Body reports in cases brought against them." reinforce a more traditional view of the WTO system.

\footnotetext{
${ }^{13}$ The Future, para. 240.

${ }^{14}$ The Future, para. 242.

${ }^{15}$ The Future, para. 243.

${ }^{16}$ The Future, para. 245.
} 
In sum, the Consultative Board's conclusions can be regarded as the manifestation of a theory of WTO law. That theory may not always be readily apparent. There are many things going on under the treaty at once: the protection of expectations, the accommodation to realities, and possibly even their integration together in some third, and overarching, interest. ${ }^{17}$ As a result the total picture frequently looks confusing.

What is useful about thinking as we have here, however, is that it permits us to comprehend what has previously appeared almost incomprehensible. Documents like the Sutherland Report become understandable as reflections not only of political and economic priorities, but also of legal principle. And as the Consultative Board itself pointed out, "[t]hose principles are little known, yet as valid and valuable now as when they were established in the last century, notably in the years after the Second World War." 18

\footnotetext{
${ }^{17}$ The interests mentioned here replicate those identified in the classic article by L. Fuller \& William R. Purdue, Jr., The Reliance Interest in Contract Damages, 46 YALE L.J. 52 (1936), and now incorporated in the RESTATEMENT OF CONTRACTS (2 $\left.{ }^{\text {nd }}\right) \S 344$ (1981). The contractual matrix in which these interests are identified is noteworthy in light of the Sutherland Report's many references to the contractualism of WTO obligations. See for instance "contractual requirements of membership" (para. 3), "the contractual detail of the WTO" (para. 200), "an institution founded on negotiated contractual commitments among governments" (para. 206), "countries should have contractual entitlement to capacity building support" (para. 306), "the WTO, in future, should contain provisions for a contractual right" (para. 311).

${ }^{18}$ The Future, para. 362.
} 